\title{
Why were the Neolithic landscapes of Bela krajina and Ljubljana Marshes regions of Slovenia so dissimilar?
}

\author{
Maja Andrič \\ Institute of Archaeology, ZRC SAZU, SI \\ maja.andric@zrc-sazu.si
}

\begin{abstract}
This paper compares the development of Holocene vegetation in Bela krajina and Ljubljana Marshes (Ljubljansko barje) regions of Slovenia. The results of pollen analysis suggest that in Bela krajina the human impact on the environment (forest clearance and burning) was very intensive throughout the Holocene and led to changes in forest composition, increased biodiversity, and the formation of a mosaic landscape. In the Ljubljana Marshes, forest burning and clearance seem less intensive, although changes in forest composition and 'anthropogenic indicator' pollen types were detected. These differences between study regions are presumably a consequence of various climates, hydrology, bedrock and land-use in the past.
\end{abstract}

IZVLEČEK - V članku je predstavljena primerjava razvoja holocenske vegetacije v Beli krajini in na Ljubljanskem barju. Rezultati pelodne analize kažejo, da je bil človekov vpliv na okolje (sekanje in požiganje gozda) v Beli krajini zelo intenziven, kar je povzročilo povečanje biodiverzitete in spremembe v sestavi gozda, oblikovala se je mozaična pokrajina. Na Ljubljanskem barju je sekanje in požiganje gozda sicer res videti nekoliko manj intenzivno, kljub temu pa na pelodnem diagramu lahko opazimo spremembe $v$ sestavi gozda in pojav 'antropogenih indikatorjev'. Te razlike med regijama so verjetno posledica različne klime, hidrologije, geološke podlage in različne izrabe pokrajine $v$ preteklosti.

KEY WORDS - palynology; Neolithic archaeology; Bela krajina; Ljubljana Marshes

\section{Introduction}

This paper aims to address the question of the diversity of the environment of the first farming communities in the region of Bela krajina and the Ljubljana Marshes area of Slovenia (Fig. 1). Differences in the composition of vegetation detected in the pollen record will be analysed in order to estimate whether they were a consequence of specific natural characteristics of the regions studied, dissimilar land-use in the past, or the size of the study sites.

In recent decades an extensive pollen analysis of sedimentary cores and samples collected during archaeological excavations was carried out on Ljubljana Marshes, so the general development of vegetation in the area is very well known (e.g. Culiberg 1991; Šercelj 1996 and references cited there, Gardner 1999a; 1999b) and the results presented in this study (a pollen analysis of 'Na mahu 1' core) accord with previous research. The question of past hydrological conditions in the area was also addressed by several researchers using sedimentological, geomorphological, archaeological and multidisciplinary palaeoecological data (e.g. Melik 1946; Šercelj 1966; Šifrer 1984; Budja 1995; Velušček 2005; Gaspari and Erič 2006; Verbič 2006; Mlekuž et al. 2006; Andrič et al. in prep., and many others). This led to various interpretations of the complex hydrological conditions in the basin (most complex in the Neolithic; many researchers would probably agree that in the early Holocene the area was covered by a freshwater lake, whereas later it became a floodplain and in some parts a peat bog). In contrast to Ljubljana 
Marshes palynological, research in Bela krajina was less extensive, and both palynologically investigated sites in the area (Mlaka and Griblje, Andrič 2001; Andrič in press) are presented in this paper. To date, no studies of past hydrology have been carried out in the area. Therefore, since hydrological conditions on Ljubljana Marshes were very complex, whereas (presumably much simpler) hydrological conditions in Bela krajina have not been investigated at all, more (detailed) research is needed in both regions in the future. Palynological research was much more intensive, and for that reason this paper will focus on only one aspect of both Neolithic landscapes: the composition of vegetation as revealed by palynological studies.

The main reasons for the variety of flora in Slovenia include its geographical position, diverse climate, relief and bedrock (Wraber 1969; Kladnik 1996; Ogrin 1996;

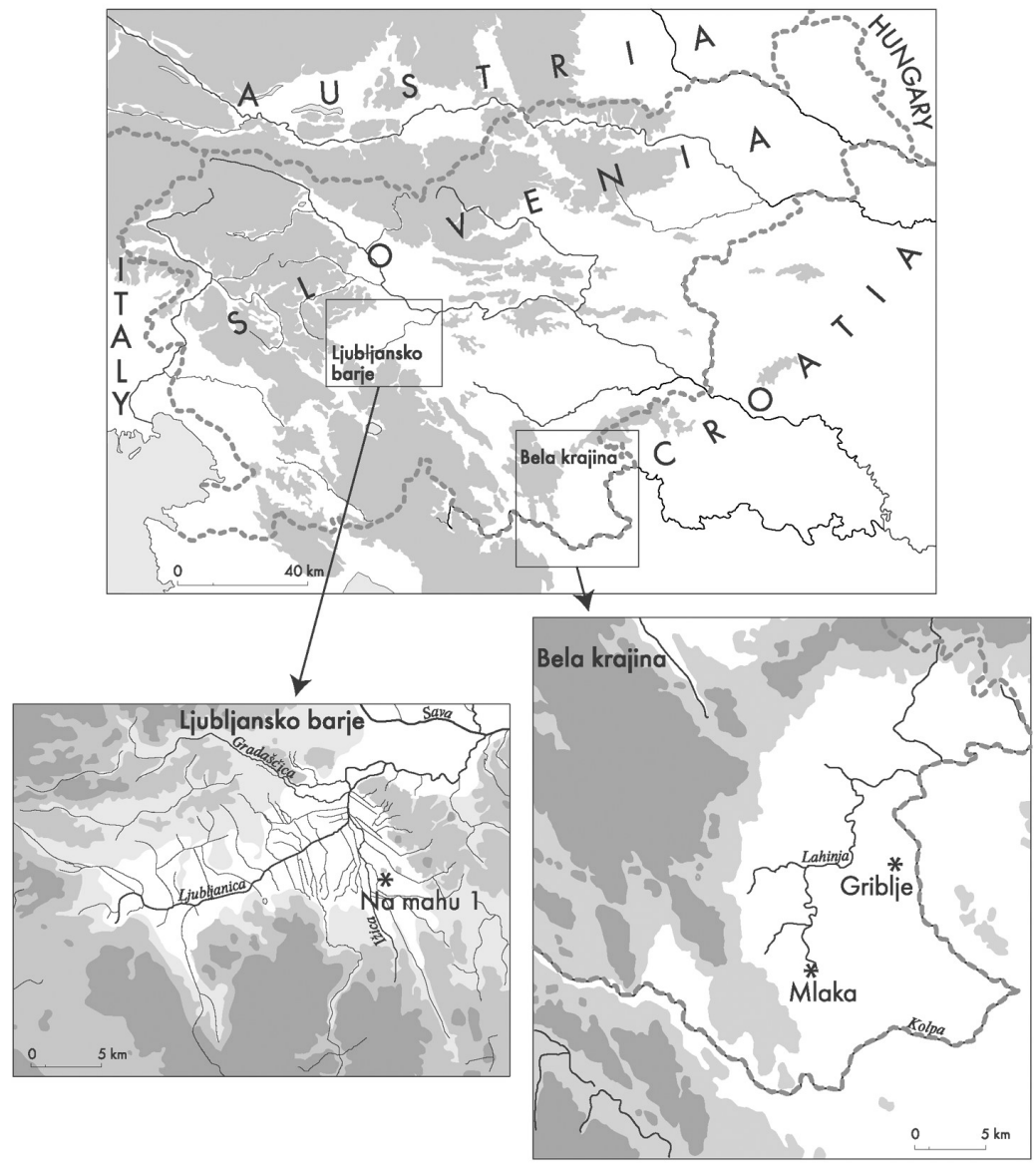

Fig. 1. Bela krajina and Ljubljana Marshes study regions and the position of palynological cores.
Perko 1998). The distinctive vegetation of Slovenia's phyto-geographic regions became apparent after $c$. 8800 calBP, whereas the onset of an intensive, largescale forest clearance, burning and the formation of the present-day landscape is dated between late prehistory and the medieval period (c. 3000 calBP 1000 calBP). Palynological research also suggests that the human impact on the vegetation was important and contributed to increasing biodiversity ( $\mathrm{An}$ drič and Willis 2003). Neolithic/Eneolithic farming communities (c. 7000-5000 calBP) lived in an environment where differences between regions had already become apparent, but large-scale forest clearances had not yet occurred. In such environments it is very difficult to distinguish the natural from the anthropogenic causes of environmental change. Therefore, in order to better understand the human impact on the vegetation, the vegetation history in the vicinity of archaeological sites was studied in detail. Sedimentary cores for pollen analysis (Fig. 1) were collected at Mlaka (Bela krajina) and 'Na mahu 1' (Ljubljana Marshes) coring locations in order to estimate the similarity/dissimilarity of vegetation development during the Holocene in both study regions. In addition to this, the vegetation history at Griblje was investigated and compared with Mlaka to assess also the intra-regional variability of Bela krajina vegetation.

\section{The Bela krajina study area}

Bela krajina (Fig. 1) is located in south-eastern Slovenia, between high Dinaric Plateaus in the west and the Kolpa River and Pannonian Plain in the east. More than half of its territory lies below $400 \mathrm{~m}$ a.s.l., on predominantly Mesozoic limestone and dolomite bedrock (Gams 1961; 1984; Buser 1984). The climate of Bela krajina is moderate continental-sub-Pannonian, with a sub-Mediterranean precipitation regime (primary precipitation is highest in autumn), and hot, dry summers. The annual amount of precipitation is between 1200 and $1300 \mathrm{~mm}$ in western parts. The average temperatures of the warmest month are between $15^{\circ} \mathrm{C}$ and $20^{\circ} \mathrm{C}$, and of the coldest month, between $-3^{\circ} \mathrm{C}$ and $0{ }^{\circ} \mathrm{C}$ (Bernot 1984; Ogrin 1996; Plut 1985).

The composition of Bela krajina forests varies according to altitude, land-use and soil type. Predominantly beech forests are characteristic of higher alti- 
tudes, whereas patchy oak-hornbeam forests grow in the lowlands (Miklavžic 1965; Wraber 1956; Marinček and Čarni 2002; Čarni et al. 2003). Meadows, fields, pastures and human-managed birch (Betula pendula) forests ('steljniki'), which were originally used as spring/summer grazing areas, spread into the lowlands due to intensive human impact in the last centuries.

Both palaeo-ecological study sites presented in this study (Mlaka and Griblje) are small lowland marshy areas with diameters of $c .30 \mathrm{~m}$ and without inflowing/outflowing streams (Fig. 1). Numerous archaeological sites, including Neolithic/Eneolithic settlements, are located close to Mlaka and Griblje (e.g. Pusti Gradac and Griblje, Arheološka najdišča Slovenije 1975; Dular 1985; Mason 2001; Phil Mason, personal communication 2005).

\section{The Ljubljana Marshes study area}

Ljubljana Marshes lies in central Slovenia (Fig. 1) at about $289 \mathrm{~m}$ a.s.l., on predominantly carbonate bedrock, with Triassic and Jurassic limestones and dolomites in southern and western parts of the basin, whereas Palaeozoic sandstones, conglomerates, shales and limestones prevail in the north and east (Mencej 1989). The bottom of the basin is covered by thick layers of Pleistocene and Holocene alluvial and lacustrine sediments (Mencej 1989; Grimšičar and Ocepek 1967; Tancik 1965; Šercelj 1965; 1967). The climate on Ljubljana Marshes is temperate-continental, with a sub- continental precipitation regime (precipitation highest in the summer) and annual precipitation between 1000 and $1300 \mathrm{~mm}$. The average temperatures of the coldest month are between $-3^{\circ} \mathrm{C}$ and $0^{\circ} \mathrm{C}$, and in the warmest month the average is between $15^{\circ} \mathrm{C}$ and $20^{\circ} \mathrm{C}($ Ogrin 1996).

Ljubljana Marsh is currently covered by meadows, fields and patchy woodlands of pine (Pinus), birch (Betula), alder (Alnus) and oak (Quercus robur). Only very small peat-bogs with ombrotrophic species have remained (Martinčič 1987). Predominantly beech (Fagus) forests grow on the hills surrounding the area (Carni et al. 2003). In the $18^{\text {th }}$ century it was much wetter than today, and mostly covered by peatbogs, smaller 'puddles' and springs (Melik 1927) and drier heather lands, with spruce (Picea), pine, alder and birch trees. However, in the second half of the $18^{\text {th }}$ century, the first drainage works in the area started, and by the end of $19^{\text {th }}$ century almost all the peat had been burnt or cut in order to obtain dry land needed for agriculture (Melik 1927).
The sedimentary core presented in this study ('Na mahu 1') was collected in the eastern part of the Ljubljana Marsh basin (Fig. 1). Archaeological sites, mostly dated to the $7^{\text {th }}$ and $6^{\text {th }}$ millennium calBP, were discovered in the vicinity of the coring location (e.g. Resnikov prekop and Maharski prekop, Dimitrijević 1997; Budja 1995; Čufar and Korenčič 2006; Velušček 2006; Čufar and Velušček 2004; Bregant 1974; 1975)

\section{Methodology}

The pollen record of three study sites, Mlaka and Griblje (G3) in Bela krajina, and 'Na mahu 1' in Ljubljana Marshes (Fig. 1) is presented and compared in this study. The detailed methodology and results for individual study sites have been published (for Mlaka and Griblje see Andrič in press) or are currently in preparation ('Na mahu 1', Andrič et al. in prep.), therefore only selected data will be presented in this paper.

All sedimentary sequences were collected by Livingstone piston corer, and standard laboratory procedures (Bennett and Willis 2002) were used for pollen analysis. The age was determined by AMS radiocarbon dating of organic carbon extracted from the sediment. The radiocarbon dates at Mlaka and Griblje were calibrated by the BCal program (hosted by the Department of Probability and Statistics at the University of Sheffield, Buck et al. on-line), which incorporates the IntCal 04 calibration dataset (Reimer et al. 2004), and these results were used for age-depth modelling in PSIMPOLL (general linear line-fitting by singular value decomposition for Griblje, and a combination of general linear line-fitting by singular value decomposition and linear interpolation for Mlaka). The conventional radiocarbon dates used for age-depth modelling are marked on each diagram. The age-depth modelling for 'Na mahu 1' core was a linear interpolation between the median values of $14 \mathrm{C}$ dates (the lower two dates were excluded from the age-depth modelling due to an error, presumably caused by the reservoir effect). The percentage pollen diagrams of selected taxa were plotted by PSIMPOLL 3.00, 4.25 and PSCOMB 3.01, C programs (Bennett 1998; Bennett on-line). They were divided into zones using binary splitting by sum of squares, and the number of significant zones was determined by the broken-stick model (Bennett 1996; 1998). Dots on the pollen diagram indicate values lower than $0.5 \%$. Palynological richness (rarefraction analysis) was also calculated by PSIMPOLL. Microscopic charcoal (in two size classes: 
$<40 \mu \mathrm{m}$ and $>40 \mu \mathrm{m})$ was counted with the pollen ('Na mahu 1' and Griblje cores) and, in addition to this, the concentration of microscopic charcoal was determined according to Clark's (1982) point count method at both Mlaka and Griblje.

\section{Results}

The results are presented on percentage pollen diagrams of selected taxa (Fig. 2) and compared in Table 1. Landscape openness, the microcharcoal record and palynological richness of all three study sites are also compared (Fig. 3). More detailed results are being published in separate publications (Andrič in press, Andric et al. in prep.). The mismatch of Mlaka and Griblje pollen diagrams (compare Fagus curves) for levels older than $c .6000$ calBP are most probably a consequence of problematic radiocarbon dating at Griblje, where levels between 50 and $61 \mathrm{~cm}$ seem to be up to $c$. 900 years 'too old' (Andrič in press).

\section{Early Holocene}

At the beginning of the Holocene (between $c .11500$ and $9000-8750$ calBP) an open, predominantly broadleaved woodland with oak (Quercus), hazel (Corylus), lime (Tilia), elm (Ulmus), pine (Pinus), birch (Betula) and spruce (Picea mostly around Ljubljana Marshes) was growing in both study regions (Fig. 2, Tab. 1). The increased concentration of microscopic charcoal suggests that forest fires were common, probably due to the arid early Holocene climate (e.g. Kutzbach and Guetter 1986; COHMAP Members 1988).

Later (at $c .9000-8750$ calBP) the forest composition suddenly changed, and thick, mostly beech ( $\mathrm{Fa}$ gus) forest started to grow in Bela krajina and Ljubljana Marshes (Fig. 2, Tab. 1). In Ljubljana Marshes this beech forest persisted until $c .6750 \mathrm{calBP}$, whereas in Bela krajina the development was much more dynamic. Slight fluctuations in beech pollen curves (some of them coincide with charcoal peaks and even with Cerealia-type pollen grain at Griblje) suggest that the forest in Bela krajina was less dense than in the Ljubljana Marshes region, and occasional smallscale landscape fires probably caused minor openings in the canopy. After $c .7800$ calBP beech (Fagus) at the Mlaka site started to decline, and by $c .7300$ calBP the percentage of tree pollen had significantly declined (with the exception of lime (Tilia), which increased), whereas herbs and monolete fern spores (Filicales) increased, suggesting the opening of the landscape (Fig. 2a). A similar change in vegetation was also detected at Griblje (Fig. 2b), where beech forest was replaced by a more open landscape, with higher percentages of pine (Pinus) and Trilete spores than at Mlaka. In contrast to Bela krajina, the hills surrounding Ljubljana Marshes basin remained very much forested with beech (Fagus), and after 7600 calBP also fir (Abies) (Fig. 2c). No such increase in fir (Abies) was detected in Bela krajina, although the forest started to regenerate at the beginning of the 7th millennium calBP.

After c. 7000 calBP, hazel (Corylus) and oak (Quercus) at Mlaka, increased and between $c$. 6700-6100 calBP hornbeam (Carpinus betulus) woodland was growing around the coring location. The Griblje forest also regenerated, and beech (Fagus), alder ( $\mathrm{Al}$ nus) and hazel (Corylus) started to increase again, but in contrast to Mlaka, there was no hornbeam (Carpinus b.) phase. The human impact on the environment around both study sites was significant and can be associated with the Neolithic/Eneolithic sites at Pusti gradac and Griblje. Small-scale forest burning (increased micro-charcoal concentration), agriculture and grazing (anthropogenic indicator taxa: Cerealiatype, Centaurea, Plantago l., Chenopodiaceae, Artemisia, Compositae lig. and Compositae tub.) was most intensive at $c .6100$ calBP (Fig. 2a, 2b).

What happened at the same time on Ljubljana Marshes? A major change in the composition of vegetation occurred between 6750 and 5600 calBP (roughly at the same time as Carpinus $b$. phase at Mlaka), when beech (Fagus) and fir (Abies) declined, whereas oak (Quercus), alder (Alnus) and hazel (Corylus) increased (Fig. 2c), but an increase in hornbeam (Carpinus betulus, best seen at Podpeško jezero, Gardner 1999b) was less significant than at Mlaka. An increased percentage of herb pollen after 6600 calBP and anthropogenic/grazing indicators (Plantago $l$.) suggest that the landscape became slightly more open, which can be associated with human activity at the Resnikov prekop settlement, located $c$. $1.5 \mathrm{~km}$ south of the coring location.

\section{Middle Holocene}

In the second half of the Holocene, shade-tolerant tree taxa started to increase in both study regions. In Bela krajina, beech (Fagus) forest spread again after 5700 calBP, but forest composition changed at c. 4800 calBP, when beech was replaced by fir (Abies) (Fig. 2a). Similarly, an increase in beech on Ljubljana Marshes is dated after $c .6000$ calBP, but this was very soon replaced by fir, which remained the most important tree taxon until $c .4500$ calBP, when spruce (Picea) and alder (Alnus) increased (Fig. 2c). The de- 


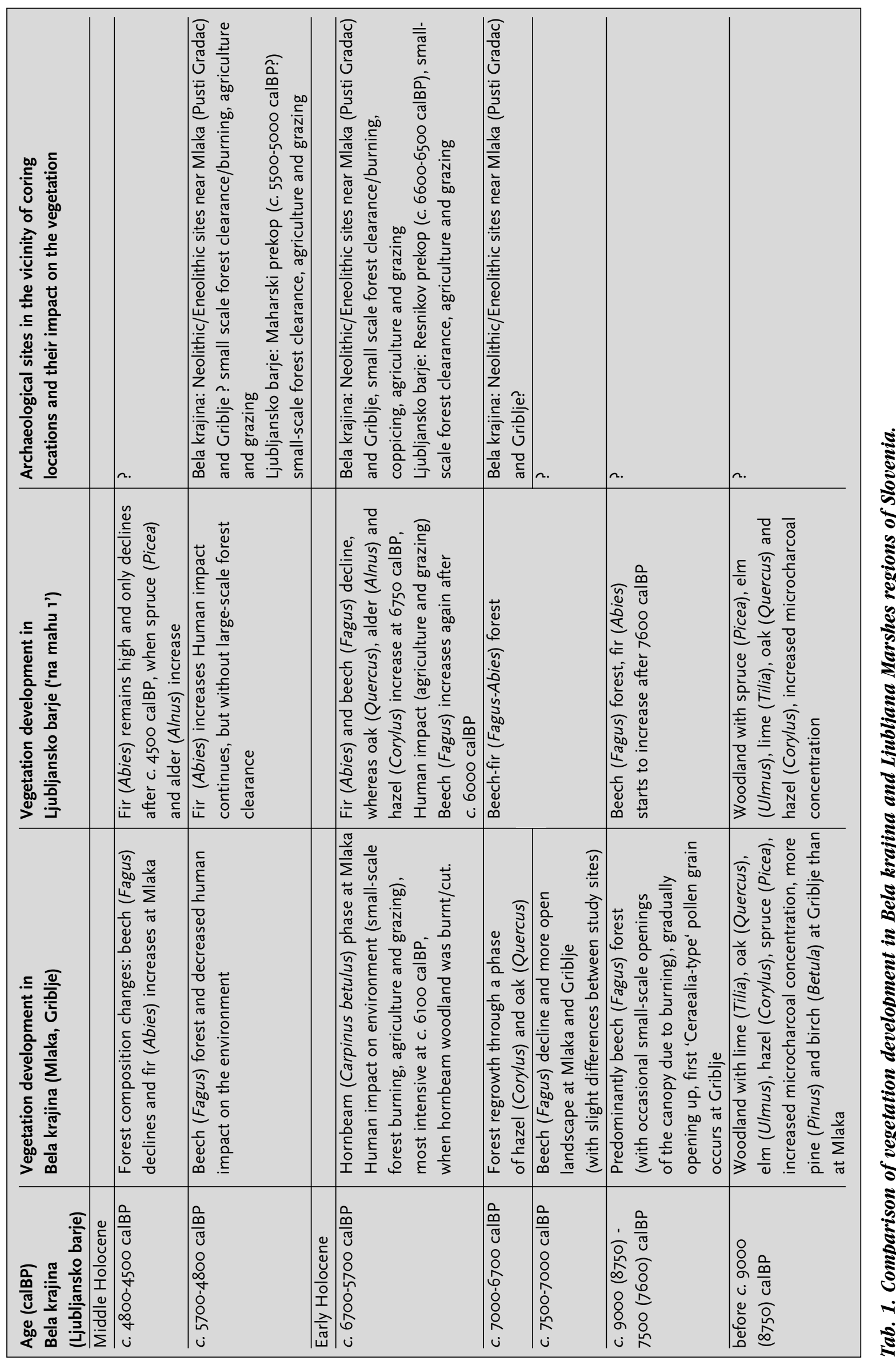




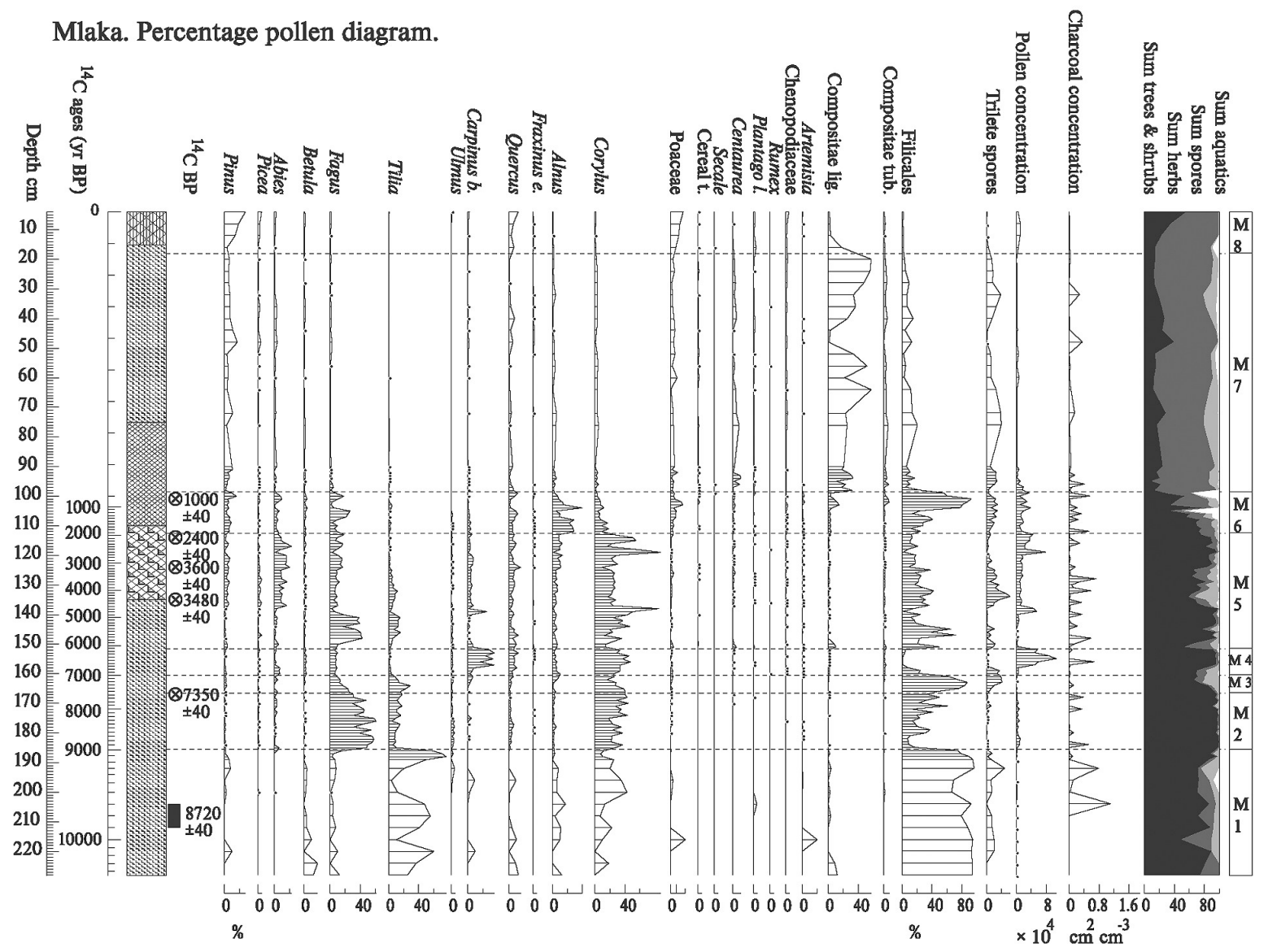

Griblje. G3. Percentage pollen diagram

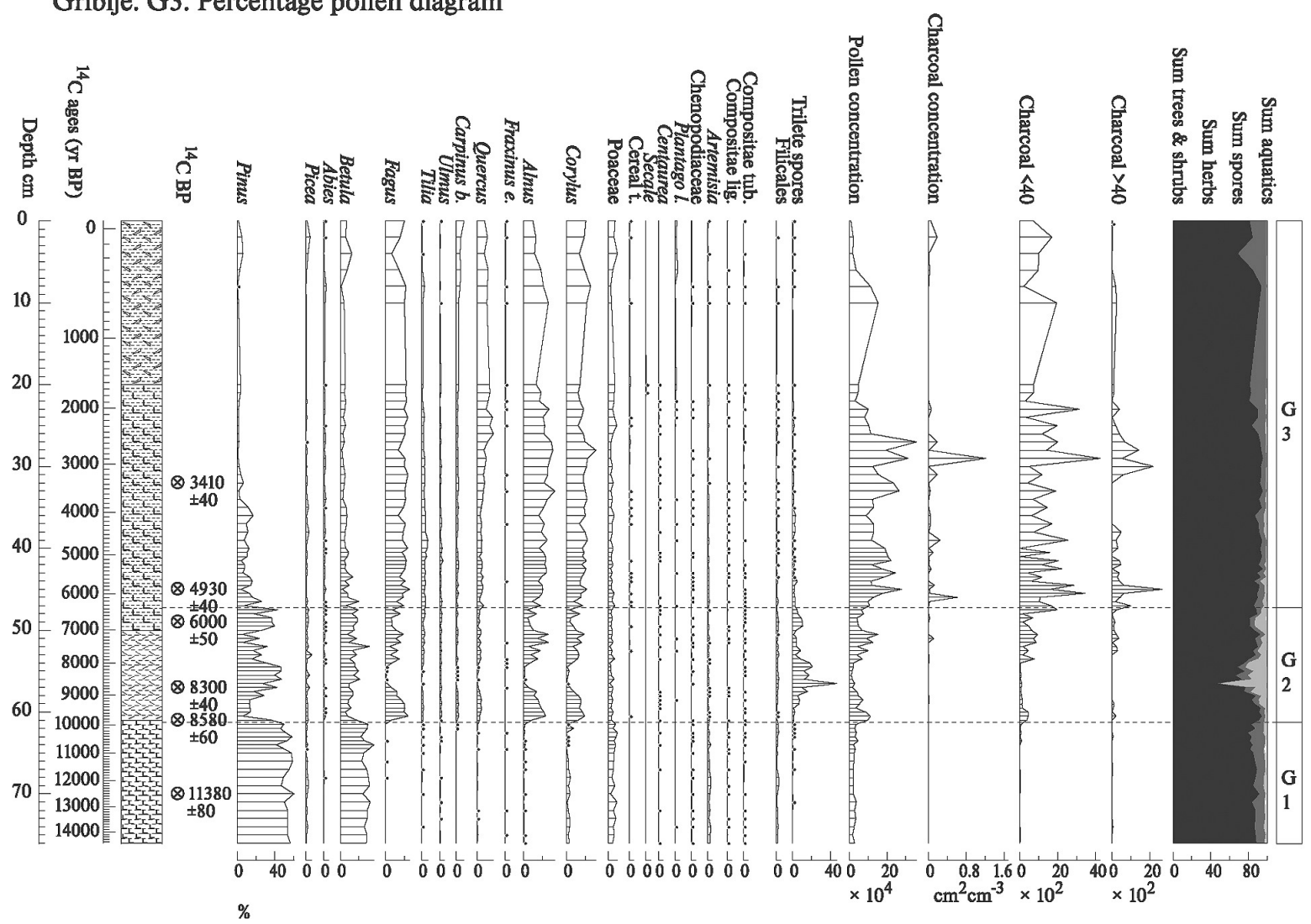




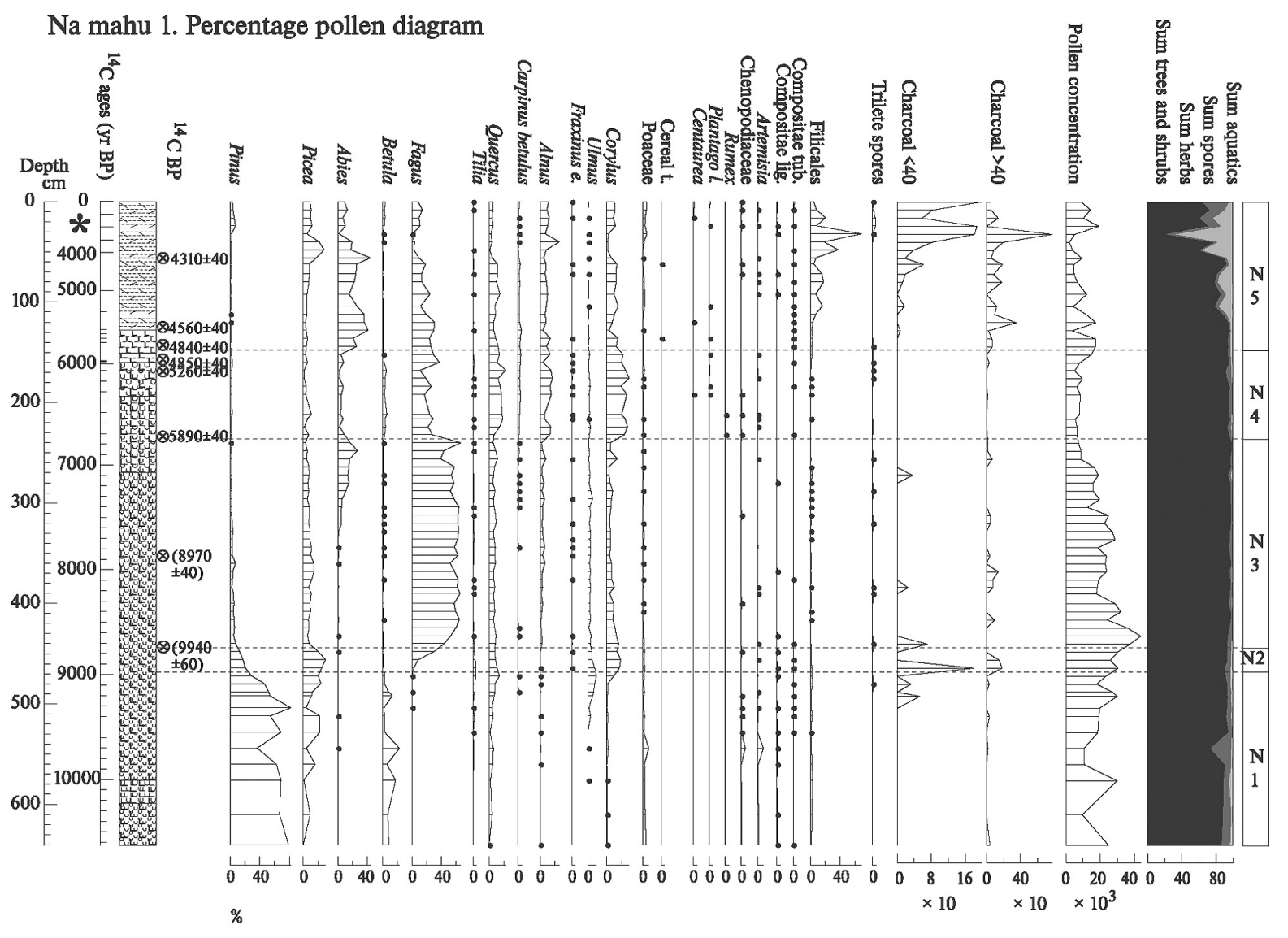

Figs. $2 a$ and $2 b$ (on previous page) and $2 c$ (up). Mlaka, Griblje (G3) and 'Na mahu 1'percentage pollen diagrams of selected taxa. * hiatus due to peat cutting/burning on Ljubljansko barje.

velopment of vegetation on Ljubljana Marshes in subsequent millennia cannot be reconstructed, since the younger sediment was destroyed by peat cutting and burning in the $18^{\text {th }} / 19^{\text {th }}$ century.

\section{Discussion}

\section{The human impact on the environment}

After comparing the pollen record from both study regions, it appears that the intensity of human impact on the environment in Bela krajina was very considerable. Constant small-scale forest burning and cutting associated with the appearance of anthropogenic indicator taxa and increased biodiversity (palynological richness, Fig. 3) was detected from at least $c .6000$ calBP, which led to changes in forest composition, increasing differences between the Mla$\mathrm{ka}$ and Griblje study sites and the formation of mosaic landscape (Andric in press).

The human impact on the environment on Ljubljana Marshes seems much less intensive; here, thick beech and beech-fir forest persisted until c. 6750 calBP. At c. 6600 calBP a minor forest clearance (Fig. 2c, 3) and anthropogenic indicator taxa were detected, but the landscape remained very much forested (as already demonstrated by previous research, Gardner $1999 a ; 1999 b)$ and the development of vegetation much less dynamic than in Bela krajina. Does this mean that in Bela krajina, Neolithic/Eneolithic settlements were more numerous and farming activities more intensive (or earlier) than on Ljubljana Marshes? Not necessarily. The differences between Bela krajina and Ljubljana Marshes could be a consequence of the natural features of the study sites (Fig. 1). Both sites in Bela krajina, Mlaka and Griblje, are small basins with diameters of $c .30 \mathrm{~m}$ and without inflowing or outflowing streams. In such small basins, which receive pollen deriving mainly from local vegetation, small-scale local changes in vegetation are very visible (Jacobson and Bradshaw 1981). In bigger basins with complex hydrology, such as Ljubljana Marshes, regional pollen prevails (Jacobson and Bradshaw 1981), so local, small-scale forest clearance is less visible in the pollen record. Considering palynological theory, therefore, these results were expected.

Despite all these differences between Bela krajina and Ljubljana Marshes, there is one similarity: an increase 


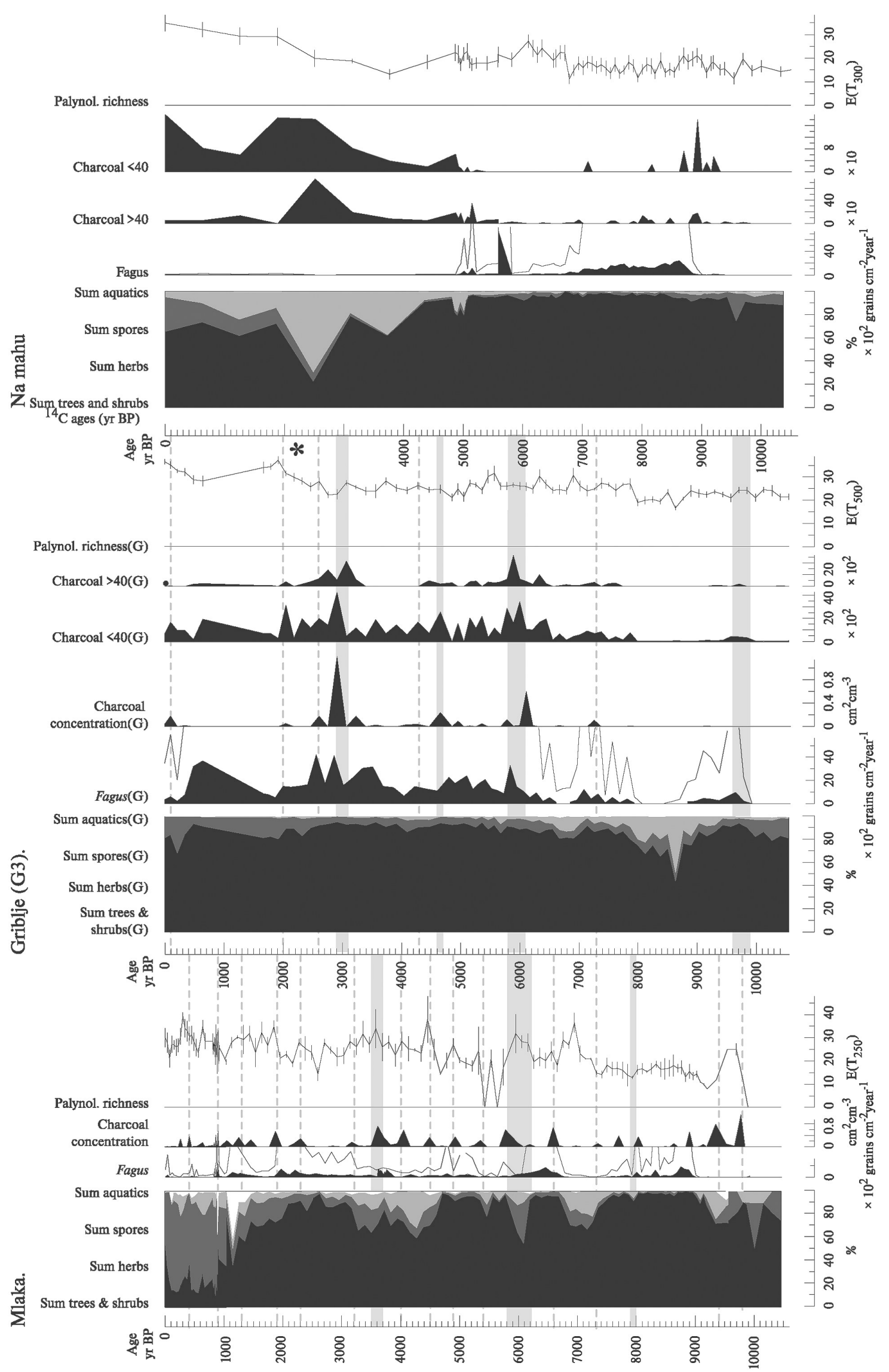

Fig. 3. Landscape openness, microcharcoal record and palynological richness at Mlaka, Griblje (G3) and 'Na mahu 1' study sites. * hiatus due to peat cutting/burning on Ljubljana Marshes. 
in biodiversity (palynological richness, Fig. 3) at the beginning of the $7^{\text {th }}$ millennium calBP $(c .7000$ calBP at Mlaka and 6700 calBP at 'Na mahu 1' core), although no major landscape forest clearance has been detected on pollen diagrams. This could probably be associated with small-scale forest clearance and the activities of early farming communities.

\section{Human impact versus climate}

Changes in forest composition and differences between the study regions can be a consequence of climatic fluctuations and/or human impact. Today, summers in Bela krajina are warmer and drier than on Ljubljana Marshes, and it is possible that a similar contrast existed in the past. Therefore, less fir (Abies), which needs a humid climate (Ellenberg 1988) was growing in Bela krajina than on Ljubljana Marshes. However, fir is susceptible to fire (Tinner et al. 1999), and it is possible that in Bela krajina it was suppressed by anthropogenic burning of the landscape. The charcoal record suggests that the vegetation around Ljubljana Marshes was not burnt so often. Why not because the lake/marshy landscape of Ljubljana Marshes was more difficult to burn, and this landscape was used instead for hunting, fishing and gathering? Due to the complex hydrological conditions, more open land probably already existed (or was regularly formed) near the edge of the lake and/or along floodplains, and very extensive forest clearance for agriculture was not needed (Willis 1995)?

Palynological research also demonstrated that differences in the composition of vegetation occurred not only between the phytogeographic regions of Slovenia, but also within each individual region. This can best be demonstrated by the differences between Mlaka and Griblje, where, although the study sites are located only $c .10 \mathrm{~km}$ apart, the vegetation history was very dissimilar. While at Mlaka (located on predominantly limestone bedrock) human pressure on the environment was intensive throughout the Holocene, and the present-day open landscape had formed by the medieval period at $c .1000$ calBP, the landscape at Griblje (on sand and clay) remained predominantly forested up to the present. This suggests that areas more suitable for agriculture were probably most intensively used.

\section{Climate}

To date no studies of local (regional) climate have been carried out, therefore changes in vegetation (e.g. forest composition) can be only compared with the global (Northern Hemisphere) climate. In both study regions beech (Fagus) establishment at the be- ginning of the $9^{\text {th }}$ millennium calBP was presumably associated with climatic change - an increase in precipitation. A similar increase in shade-tolerant tree taxa also occurred in other regions of Slovenia ( $A n$ drič and Willis 2003) and neighbouring countries (Abies expansion in the lowlands of the southern Alps, Tinner et al. 1999; Gobet et al. 2000; Tinner and Lotter 2006; and Fagus increase in Dalmatia, Schmidt et al. 2000) and it seems that this palaeoenvironmental change was of regional extent. It was limited to the areas south of the Alps, where a continental climate regime had already been replaced by an Atlantic climate regime at about 9100 calBP, whereas north of the Alps, the Atlantic climate is associated with the $8.2 \mathrm{ky}$ BP event (Tinner and Ammann 2001).

At the beginning of the $8^{\text {th }}$ millennium calBP, beech (Fagus) in Bela krajina started to decline, and by $c$. 7300 calBP, the beech forest had been replaced by a more open landscape. Fagus decline is limited only to Bela krajina (the Ljubljana Marshes region remained very much forested), so it seems unlikely that it would have been triggered by cold global climatic fluctuations, such as the $8.2 \mathrm{ky}$ BP event (Alley et al. 1993; Meese et al. 1994; Stager and Mayewski 1997; Haas et al. 1998; Alley and Ágústsdóttir 2005). However, the impact of precipitation fluctuations might have been more important than the temperature, especially since the $8.2 \mathrm{ky}$ event is assumed to have been dry in the lowlands (Haas et al. 1998), with lower lake levels north and south of $50^{\circ} \mathrm{N}$ and $43^{\circ} \mathrm{N}$ respectively (Magny and Begeot 2004). It is possible that in the $8^{\text {th }}$ millennium calBP climatic differences between Bela krajina and the Ljubljana Marshes were more pronounced than today, and forest composition in Bela krajina was affected by warm and dry summers, whereas at the same time no major change in forest composition took place on the Ljubljana Marshes.

Is it possible that Fagus decline was caused by the impact of hunter-gatherers and/or farmers on the landscape? Yes. Admittedly, no archaeological sites reliably dated before $c$. 7000 calBP have been discovered in Bela krajina, but this option cannot be completely ruled out, and further archaeological and multi-proxy palaeo-ecological research of the regional climate is needed.

After $c .6700$ calBP, the percentage of beech (Fagus) and fir (Abies) was low in both study regions. This is most probably a consequence of significant human impact (forest clearance and burning), and coincides 
with a major climatic reversal after $8.2 \mathrm{ka}$ calBP (Stager and Mayewski 1997; Alley and Ágústsdóttir 2005), when the oceanic early Holocene climate with enhanced westerly airflow was presumably replaced by a more meridional flow pattern, with anti-cyclonic summer conditions, and thus a dry climate and lower lake levels in the period between $c$. 68005700 calBP (Seppä and Birks 2001).

After $c$. 6000-5700 calBP, beech (Fagus), and later also fir (Abies), increase in both regions, with a slightly decreased human impact on the environment. This could have been associated with the cold and wet climate in the $6^{\text {th }}$ millennium calBP (Mayewski et al. 2004; Haas et al. 1998; Magny 2004; Magny and Haas 2004; Denton and Karlén 1973; Seppä and Birks 2001; O'Brien et al. 1995; Bond et al. 1997).

\section{Conclusions}

The above described differences between Bela krajina and the Ljubljana Marshes are presumably a consequence of different climates (wetter/colder in the Ljubljana Marshes region?), hydrology, topography and bedrock, as well as archaeological settlement patterns and land-use (more frequent landscape burning in Bela krajina) in the past. However, different natural characteristics and thus the pollen source area of individual study sites should not be ignored.
While at Bela krajina, where all the study sites are small marshes without inflowing/outflowing streams, the local Neolithic impact on the landscape is very visible, the Ljubljana Marshes study site is much bigger and has a more complex and changeable hydrology, which affected the pollen source area. Here, a weak local human impact on the vegetation is more difficult to detect.

How to proceed: more archaeological research is needed in both regions in order to better understand the economy of past societies and their impact on the vegetation. Especially in Bela krajina, where natural conditions are not very favourable for the preservation of archaeological sites or animal and plant remains, more information about archaeological settlement patterns and the economy during the transition from hunting-gathering to the first farming communities would be very valuable. More multi-proxy palaeo-ecological (palaeo-climatological and palaeohydrological) research is also needed, since the impact of climate fluctuations on the vegetation and hydrology was significant.

\section{ACKNOWLEDGEMENTS}

This research was funded by the Slovenian Research Agency, project no. Z6-4074-0618-03. I am very grateful to Mateja Belak, who prepared the figures.

\section{REFERENCES}

ALLEY R. B., MEESE D. A., SHUMAN C. A., GOW A. J., TAYLOR K. C., GROOTES P. M., WHITE J. W., RAM M., WAD DINGTON E. D., MAYEWSKI P. A., ZIELINSKI G. A. 1993. Abrupt increase in Greenland snow accumulation at the end of Younger Dryas event. Nature 362: 527-529.

ALLEY R. B., ÁGÚSTSDÓTTIR A. M. 2005. The 8k event: cause and consequences of a major Holocene abrupt climate change. Quaternary Science Reviews 24: 11231149.

ANDRIČ M. 2001. Transition to farming and human impact on the Slovenian landscape. DPhil thesis. University of Oxford.

in press (2007). The Holocene vegetation development in Bela krajina (Slovenia) and the impact of first farmers on the landscape. The Holocene 17 (6).
ANDRIČ M., KROFLIČ B., TOMAN M. J., OGRINC N., DOLENEC T., DOBNIKAR M., ČERMELJ B. in prep. Changes of Late Quaternary vegetation and hydrology on Ljubljansko barje (Slovenia).

ANDRIČ M., WILLIS K. J. 2003. The phytogeographical regions of Slovenia: a consequence of natural environmental variation or prehistoric human activity? Journal of Ecology 91: 807-821.

ARHEOLOŠKA NAJDIŠČA SLOVENIJE 1975. S. Gabrovec, S. Jesse, P. Petru, J. Šašel and F. Truhlar (eds.), SAZU and Inštitut za arheologijo, Ljubljana.

BENNETT K. D. 1996. Determination of the number of zones in a biostratigraphical sequence. New Phytologist 132: $155-170$. 
1998. Documentation for PSIMPOLL 3.00 and PSCOMB 1.03: C programs for plotting pollen diagrams and analysing pollen data. Cambridge. on-line http:// chrono.qub.ac.uk/psimpoll/psimpoll.html.

on-line http://chrono.qub.ac.uk/psimpoll/psimpoll.html.

BENNETT K. D., WILLIS K. J. 2002. Pollen. In J. P. Smol, H. J. Birks and W. M. Last (eds). Tracking Environmental Changes Using Lake Sediments. Vol. 3. Terrestrial, Algal and Siliceous Indicators, Kluwer Academic Publishers, Dordrecht: 5-32.

BERNOT F. 1984. Opis klimatskih razmer občin Trebnje, Novo mesto, Metlika in Črnomelj. In D. Plut and M. Ravbar (eds.), Dolenjska in Bela krajina (Prispevki za 13. Zborovanje slovenskih geografov $v$ Dolenjskih Toplicah od 12.-14. Oktobra 1984), Geografsko društvo Slovenije, Ljubljana: 89-98.

BOND G., SHOWERS W., CHESBEY M., LOTTI R., ALMASI P., DEMENOCAL P., PRIORE P., CULLEN H., HAJDAS I., BONANI G. 1997. A pervasive millennial-scale cycle in north Atlantic Holocene and Glacial climates. Science 278: 1257-1266.

BREGANT T. 1974. Kolišče ob Maharaskem prekopu pri Igu - raziskovanje leta 1972. Poročilo o raziskovanju neolita in eneolita $v$ Sloveniji 3: 39-68.

1975. Kolišče ob Maharskem prekopu pri Igu - raziskovanja 1973. in 1974. leta. Poročilo o raziskovanju neolita in eneolita $v$ Sloveniji 4: 7-114.

BUDJA M. 1995. Spreminjanje naravne in kulturne krajine v neolitiku in eneolitiku na Ljubljanskem barju I. Poročilo o raziskovanju paleolitika, neolitika in eneolitika v Sloveniji 22: 163-181.

BUCK et al. on-line http://bcal.shef.ac.uk/home.html.

BUSER S. 1984. Nekaj novosti o geologiji Dolenjske. In D. Plut and M. Ravbar (eds.), Dolenjska in Bela krajina (Prispevki za 13. zborovanje slovenskih geografov v Dolenjskih Toplicah od 12.-14. Oktobra 1984), Geografsko društvo Slovenije, Ljubljana: 26-37.

CLARK R. L. 1982. Point count estimation of charcoal in pollen preparations and thin sections of sediments. Pollen et spores 24: 523-532.

COHMAP Members. 1988. Climatic changes of the last 18000 years: observations and model stimulations. Science 241: 1043-1052.

CULIBERG M. 1991. Late Glacial vegetation in Slovenia. Kasnoglacialna vegetacija v Sloveniji. Dela SAZU 4/29. SAZU, Ljubljana.
ČARNI A., MARINČEK A., SELIŠKAR A., ZUPANČIČ M. 2003. Vegetation map of Slovenian forest plant associations, Institut of Biology, Scientific Research Centre of the Slovenian Academy of Sciences and Arts, on-line http://bijh.zrcsazu.si/bio/si/zbirke/400/400.asp

ČUFAR K, KORENČIČ T. 2006. Raziskave lesa z Resnikovega prekopa in radiokarbonsko datiranje. Investigations of wood from Resnikov prekop and radiocarbon dating. In A. Velušček (ed.), Resnikov prekop, najstarejša koliščarska naselbina na Ljubljanskem barju. Resnikov prekop, the oldest pile-dwelling settlement in the Ljubljansko barje, Opera Instituti Archaeologici Sloveniae 10. Založba ZRC in Inštitut za arheologijo ZRC SAZU, Ljubljana: 123127.

ČUFAR K., VELUŠČEK A. 2004. Hočevarica: absolutno datiranje. Hočevarica: absolute dating. In A. Velušček (ed.), Hočevarica. Eneolitsko kolišče na Ljubljanskem barju. Hočevarica. An Eneolithic pile dwelling in the Ljubljansko barje, Opera Instituti Arcaheologici Sloveniae 8, Založba ZRC in Inštitut za arheologijo ZRC SAZU, Ljubljana: 263-280.

DENTON G. E., KARLÉN W. 1973. Holocene climate variations - their pattern and possible cause. Quaternary Research 3: 155-205.

DIMITRIJEVIĆ S. 1979. Lasinjska kultura. In A. Benac (ed.), Praistorija jugoslavenskih zemalja 3, Svjetlost, OOUR izdavačka djelatnost and Akademija nauka i umjetnosti Bosne i Hercegovine, Sarajevo: 137-181.

DULAR J. 1985. Arheološka topografija Slovenije. Topografsko področje XI (Bela krajina). SAZU, Ljubljana.

ELLENBERG H. 1988. Vegetation ecology of central Europe. Cambridge University press. Cambridge.

GAMS I. 1961. H geomorfologiji Bele krajine. Geografski zbornik 6: 191-240.

1984. Regionalizacija nizke jugovzhodne Slovenije. In D. Plut and M. Ravbar (eds.), Dolenjska in Bela krajina (Prispevki za 13. zborovanje slovenskih geografov $v$ Dolenjskih Toplicah od 12.-14. oktobra 1984), Geografsko društvo Slovenije, Ljubljana: 7-25.

GARDNER A. 1999a. The Impact of Neolithic Agriculture on the Environments of South-East Europe. PhD Thesis. University of Cambridge.

1999b. The ecology of Neolithic environmental impacts - re-evaluation of existing theory using case studies from Hungary \& Slovenia. In M. Budja (ed.), $\sigma^{\text {th }}$ Neolithic Studies. Documenta Praehistorica 26: 163183. 
GASPARI A., ERIČ M. 2006. Podvodne arheološke raziskave struge Ljubije v Zalogu pri Verdu. Undervater research in the bed of the Ljubija stream at Zalog near Verd. In A. Gaspari (ed.), Zalog pri Verdu, Tabor kamenodobnih lovcev na zahodnem robu Ljubljanskega barja. Zalog near Verd. Stone Age hunters' camp at the western edge of the Ljubljansko barje. Opera Instituti Archaeologici Sloveniae 11, Založba ZRC in Inštitut za arheologijo ZRC SAZU, Ljubljana: 11-31.

GOBET E., TINNER W., HUBSCHMID P., JANSEN I., WEHRLI M., AMMANN B., WICK L. 2000. Influence of human impact and bedrock differences on the vegetational history of the Insubrian Southern Alps. Vegetation History and Archaeobotany 9: 175-178.

GRIMŠIČAR A., OCEPEK V. 1967. Vrtini BV-1 in BV-2 na Ljubljanskem barju. Geologija 10: 279-303.

HAAS J. N., RICHOZ I., TINNER W., WICK L. 1998. Synchronous Holocene climatic oscillations recorded on the Swiss plateau and at timberline in the Alps. The Holocene 8,3: 301-309.

JACOBSON G. L., BRADSHAW R. H. W. 1981. The selection of sites for palaeovegetational studies. Quaternary Research 16: 80-96.

KLADNIK D. 1996. Naravnogeografske členitve Slovenije. Geografski vestnik 68: 123-159.

KUTZBACH J. E., GUETTER P. J. 1986. The influence of changing orbital parameters and surface boundary conditions on climate simulations for the past 18000 years. Journal of the Atmospheric Sciences 43 (16): 17261759 .

MAGNY M. 2004. Holocene climate variability as reflected by mid-European lake-level fluctuations and its probable impact on prehistoric human settlements. Quaternary International 113: 65-79.

MAGNY M., BÉGEOT C. 2004. Hydrological changes in the European midlatitudes associated with freshwater outbursts from Lake Agassiz during the Younger Dryas event and the early Holocene. Quaternary Research 61: 181192.

MAGNY M., HAAS J. N. 2004. A major widespread climatic change around $5300 \mathrm{cal}$. yr BP at the time of the Alpine Iceman. Journal of Quaternary Science 19(5): 423-430.

MARINČEK L., ČARNI A. 2002. Komentar $k$ vegetacijski karti gozdnih združb Slovenije $v$ merilu 1:400 000. Commentary to the vegetation map of forest communities of Slovenia in a scale of 1:400 000, Založba ZRC and Biološki inštitut Jovana Hadžija ZRC SAZU, Ljubljana.
MARTINČIČ A. 1987. Fragmenti visokega barja na Ljubljanskem barju. High bog fragments on Ljubljansko barje (The Ljubljana Moor). Scopolia 14: 1-53.

MASON P. 2001. Griblje in problem nižinskih arheoloških kompleksov v Sloveniji. Griblje and the problem of lowland archaeological complexes in Slovenia. Varstvo spomenikov. Journal for the Protection of Monuments 39: 727.

MAYEWSKI P. A., ROHLING E. E., STAGER J. C., KARLÉN W. MAASCH K. A., MEEKER L. D., MEYERSON E. A., GASSE F., VAN KREVELD S., HOLMGREN K., LEE-THORP J., ROSQVIST G., RACK F., STAUBWASSER M., SCHNEIDER R. R., STEIG E. J. 2004. Holocene climate variability. Quaternary Research 62: 243-255.

MEESE D. A., GOW A. J., GROOTES P., MAYEWSKI P. A., RAM M., STUVIER M., TAYLOR K. C., WADDINGTON E. D., ZIELINSKI G. A. 1994. The accumulation record from the GISP2 core as an indicator of climate change throughout the Holocene. Science 266: 1680-1682.

MENCEJ Z. 1989. Prodni zasipi pod jezerskimi sedimenti Ljubljanskega barja. The gravel fill beneath the lacustrine sediments of the Ljubljansko barje. Geologija 31-32: 517-553.

MELIK A. 1927. Kolonizacija Ljubljanskega barja, Tiskovna zadruga. Ljubljana.

1946. Ljubljansko mostiščarsko jezero in dediščina po njem. Dela SAZU 1(5). ZRC SAZU, Ljubljana.

MIKLAVŽIČ J. 1965. Premena belokranjskih steljnikov v gozdove. Zbornik inštituta za gozdno in lesno gospodarstvo Slovenije 4: 1-87.

MLEKUŽ D., BUDJA M., OGRINC N. 2006. Complex settlement and the landscape dynamic of the Iščica floodplain (Ljubljana Marshes, Slovenia). In M. Budja (ed.), $13^{\text {th }} \mathrm{NeO}$ lithic Studies. Documenta Praehistorica 33: 253-271.

O'BRIEN S. R., MAYEWSKI P. A., MEEKER L. D., MEESE D. A., TWICKLER M. S., WHITLOW S. I. 1995. Complexity of Holocene Climate as reconstructed from a Greenlad ice core. Science 270: 1962-1964.

OGRIN D. 1996. Podnebni tipi v Sloveniji. Geografski vestnik 68: 39-56.

PERKO D. 1998. The regionalization of Slovenia. Regionalizacija Slovenije. Geografski zbornik 38: 11-57.

PLUT D. 1985. Pokrajinske (prirodoslovno-geografske) poteze Bele krajine. In J. Dular (ed.), Arheološka topografija Slovenije. Topografsko področje XI. Bela krajina, Dela SAZU, SAZU, Ljubljana: 13-15. 
REIMER P. J. et al. 2004. INTCAL04 terrestrial radiocarbon age calibration, 0-26 cal kyr BP. Radiocarbon 46: 10291058.

SCHMIDT R., MÜLLER J., DRESCHER-SCHNEIDER R., KIRSAI R., SZEROCZYNSKA K., BARIČ A. 2000. Changes in lake level and trophy at Lake Vrana, a large karstic lake on the Island of Cres (Croatia), with respect to palaeoclimate and antrophogenic impacts during the last approx. 16000 years. Journal of Limnology 59(2): 113-130.

SEPPÄ H., BIRKS H. J. B. 2001. July mean temperature and annual precipitation trends during the Holocene in the Fennoscandian tree-line area: pollen-based climate reconstructions. The Holocene 11(5): 527-539.

STAGER J. C., MAYEWSKI P. A. 1997. Abrupt early to midHolocene climatic transition registered at the Equator and the Poles. Science 276: 1834-1836.

ŠERCELJ A. 1965. Paleobotanične raziskave in zgodovina Ljubljanskega barja. Geologija 8: 5-28.

1966. Pelodne analize pleistocenskih in holocenskih sedimentov Ljubljanskega barja. Razprave SAZU 4 (9). SAZU, Ljubljana.

1967. Razvoj tal južnega dela Ljubljane v luči pelodnih raziskav. Razprave SAZU 4/10(7). SAZU, Ljubljana: 279-302.

1996. Začetki in razvoj gozdov v Sloveniji. The origins and development of forests in Slovenia. Dela SAZU 4/35, SAZU, Ljubljana.

ŠIFRER M. 1984. Nova dognanja o geomorfološkem razvoju Ljubljanskega barja. Geografski zbornik 23: 9-53.

TANCIK R. 1965. Pedološke značilnosti Ljubljanskega barja. Geologija 8: 58-79.

TINNER W., AMMANN B. 2001. Holocene timberline fluctuations and climate variability. PAGES News 9(3): 9-11.

TINNER W., HUBSCHMID P., WEHRLI M., AMMANN B., CONDERA M. 1999. Long-term forest fire ecology and dy- namics in southern Switzerland. Journal of Ecology 87: 273-289.

TINNER W., LOTTER A. F. 2006. Holocene expansions of Fagus sylvatica and Abies alba in Central Europe: where are we after eight decades of debate? Quaternary Science Reviews 25(5-6): 526-549.

VELUŠČEK A. 2005. Iška Loka - bronastodobno naselje na obrobju Ljubljanskega barja. Iška loka - a Bronze Age settlement on the edge of the Ljubljansko barje. Arheološki vestnik 56: 73-89.

2006. Resnikov prekop - sondiranje, arheološke najdbe, kulturna opredelitev in časovna umestitev. Resnikov prekop - sample trenching, archaeological finds, cultural and chronological classification. In A. Velušček (ed.), Resnikov prekop, najstarejša koliščarska naselbina na Ljubljanskem barju. Resnikov prekop, the oldest pile-dwelling settlement in the Ljubljansko barje, Opera Instituti Archaeologici Sloveniae 10, Založba ZRC in Inštitut za arheologijo ZRC SAZU, Ljubljana: 19-85.

VERBIČ T. 2006. Geološki in pedološki pregled sedimentov iz jedrnikov. Geological and pedological analysis of sediments from core samples. In A. Gaspari (ed.), Zalog pri Verdu, Tabor kamenodobnih lovcev na zahodnem robu Ljubljanskega barja. Zalog near Verd. Stone Age hunters' camp at the western edge of the Ljubljansko barje. Opera Instituti Archaeologici Sloveniae 11, Založba ZRC in Inštitut za arheologijo ZRC SAZU, Ljubljana: 3337.

WILLIS K. J. 1995. Pollen-sedimentological evidence for the beginning of agriculture in southeastern Europe and Anatolia. Poročilo o raziskovanju paleolitika, neolitika in eneolitika $v$ Sloveniji 22: 9-24.

WRABER M. 1956. Gozdna in steljniška vegetacija Bele krajine. Ljubljana, unpublished report.

1969. Pflanzengeographische Stellung und Gliederung Sloweniens. Vegetatio 17: 176-199. 